\title{
ICE BREAKER: A STRATEGY TO ENHANCE STUDENT'S ABILITY IN SPEAKING AT ISLAMIC JUNIOR HIGH SCHOOL OF SAWIT SEBERANG, LANGKAT REGENCY
}

\author{
Sholihatul Hamidah Daulay, Ernita Daulay, Sinta \\ E-mail:lia_hamida@yahoo.com \\ Universitas Islam Negeri Sumatera Utara \\ Medan, Indonesia
}

\begin{abstract}
This present research aims to enhance students' speaking skills through Ice Breaking at an Islamic Junior High School in Sawit Seberang, Langkat Regency. The study used Classroom Action Research comprising two cycles joined by 40 students of eight graders. Each cycles consisted of two meetings. The data were gained from students' scores in pre-test, post-tests as well as students' responses. The findings show that there was a significant improvement on students' speaking skills after the use of Ice Breaker strategy. It can be seen from the students' score in every cycle. In Pre-Test, there were only 30 percent of students whose score up to 75. In Post-Test I, 52.5 percent of students reached the score up to 75 and it improved until 80 percent of students in post-test II. In addition to this, the students responded well and showed enthusiasm after the use of Ice Breaker strategy in speaking skill.
\end{abstract}

Keywords: Ice breaker, Speaking, Islamic Junior High School.

\section{INTRODUCTION}

Speaking is an activity to express feeling and idea orally. There are some examples of speaking activities such as dialogue, interview, speech act, etc. In teaching and learning process, students commonly make mistakes in expressing their ideas into a good spoken discourse. One of the problems existing in English teaching and learning at Junior Islamic School Sawit Seberang, Langkat Regency is that the teacher still uses the traditional strategy to teach English especially speaking. It may result in the lack of students' motivation to use English as their daily conversation at school. Even worse, most of the students do not know how to start speaking English even in a simple conversation with their friends. In fact, they have learnt many things in English but they are not able to use English in spoken language.

As an important part of succeeding the students, teachers should be creative to design many communication activities in the classroom that urge and motivate students to use the language actively and productively. For example, in speaking class the students should be served with conductive learning activity. Then, they can practice English as well as possible. However, the students sometimes face many problems in speaking performance because of many factors such as less self-confidence when speaking in front of 
the class, they have low motivation from their teacher in the learning process, etc. The students seldom use English to communicate with their friends in the class when they are learning English. Therefore, it is important to stimulate the students to speak up in the class. Based on the above rationales, the researchers chose Ice Breaker strategy to make the students become active to enhance their speaking ability.

\section{REVIEW OF RELATED LITERATURE}

Santoso (2017) said that speaking is an interactive process in constructing meaning which involves producing, receiving, and processing information. In this case, its peaks of constructed forms and meanings depend on the context in which the conversation takes place, participants involved in speaking, experience, the physical environment and the purpose of speaking. A person is said to be able to speak if he is able to anticipate and produce patterns expected by a particular discourse situation. According to Brown and Yule (2008), there are three functions of speaking: talks as interaction, talk as transaction, talk as performance. Each of these speech activities is quite distinct in terms of form and function and requires different teaching approaches.

\section{Talk as interaction}

Speaking as interaction refers to the interaction which serves a primarily social function. When people meet, they exchange greetings, engage in small speaking and chit chat, recount recent experiences because they wish to be friendly and to establish a comfortable zone of interaction with others. The focus is more on the speaker and how they wish to presents themselves to each other.

\section{Talk as performance}

Speaking as performance refers to public speaking; it is a talk which transmits information before and audience such as public announcements and speeches. Speaking as performance tends to be in form of monolog rather than dialogue, often follow a recognizable format and it is closer to written language than conversational language.

\section{Speaking as transaction.}

Speaking as transaction refers to situation where the focus is on the message about what is said or achieved in order to make people understood clearly and accurately.

In brief, speaking English can be interpreted as a skill to express ideas, thoughts and feelings through oral speech by paying attention to the functions of English which include mastery of pronunciation, vocabulary, grammar, fluency, and understanding.

Said (2010) argues that Ice Breaker is a game or activity that serves to change the atmosphere of ice in the group. In short, Ice Breaker is a transition from boring situations, drowsiness, saturation and tension to relax, excitement, not drowsiness, attention, and compassion to listen or to see people who speak in front of class or meeting room. The advantages of using Ice Breaker strategy are, for instance, more contextual with the situation and condition of learning faced at the moment, teachers are more creative to 
engage the students more interactively, and the saturation experienced by the students can quickly be overcome.

\section{METHODS}

The research is Classroom Action Research (CAR). CAR is a type of research that splits both process and outcome and conducts action in its classroom to enhance the quality of speaking. This present action research tries to identify the problem that happened in the teaching and learning class related to the students' speaking skills and then decides an action to overcome the problems.

There were four phases conducted namely planning, action, observation and reflecting. These four phases were done in two cycles in which each cycle consisted of four stages. This research was conducted at Junior Islamic School Sawit Seberang, Langkat Regency. The population of this research was the eight grade students of Junior Islamic School Sawit Seberang, Langkat Regency. The sample students consisted of 40 students in the classroom, with detail of 25 male students and 15 female students.

Tests were used by the researcher as the instrument to get the data that were both quantitative and qualitative data. The test given to students speaking was the test based on material of Asking and Giving Opinion at eight grade students of junior high school. In this research, the researcher used quantitative data in Pre-Test, Post-Test I, and Post-Test II to obtain students' speaking skill. Pretest and post-test were used to know the different achievements between the students' speaking skill before and after implementig the strategy. Before the pretest and posttest were given to the students in the class, the researcher had analyzed the students' ability in speaking test. In terms of qualitative data, they were used to describe the situation during teaching-learning process. They are analyzed from interview result, observation sheets, and diary notes. The quantitative data were used to analyze students' scores. To know the mean of students' score for each cycle, the researcher applied the formula:

$X=\frac{\sum X}{N} \mathrm{X} 100 \%$

Notes:

$\mathrm{X}$ : The mean of students' score

$\sum \mathrm{X}$ : The total score of students

$\mathrm{N}$ : the number of students

Next, to categorize the number of students who passed the test successfully, they had to get minimum 75 score. Hamzah and Nurdin (2011) state, "a student is successful in learning if he gets 75 , while a class is successful in learning if they get 85 or more.”

To categorize the number of the students who passed the test successfully, the calculation will be as follows:

$$
P=\frac{\mathrm{R}}{\mathrm{T}} \times 100 \%
$$


Where:

$\mathrm{P}=$ percentage of students who gets score 75

$\mathrm{R}=$ the number of students who gets score more than 75

$\mathrm{T}=$ the total number of students who do the test

\section{FINDINGS AND DISCUSSION}

Based on the mean of students' score in Pre-Test, Post-Test I, and Post-Test II that can be seen in the following table, the researcher concluded that the students' speaking skill increased after the use of Ice Breaker strategy.

Students' score in Pre-Test, Post-Test I and Post-Test II

\begin{tabular}{|c|c|c|c|c|}
\hline No & Initial & Pre-Test & Post-Test I & Post-Test II \\
\hline 1 & IV & 40 & 60 & 65 \\
\hline 2 & RI & 60 & 60 & 65 \\
\hline 3 & DW & 40 & 65 & 75 \\
\hline 4 & BU & 45 & 70 & 75 \\
\hline 5 & EA & 40 & 60 & 75 \\
\hline 6 & $\overline{\mathrm{AA}}$ & 75 & 75 & 75 \\
\hline 7 & AS & 65 & 95 & 100 \\
\hline 8 & RN & 70 & 75 & 80 \\
\hline 9 & ML & 70 & 80 & 85 \\
\hline 10 & $\mathrm{AO}$ & 75 & 80 & 85 \\
\hline 11 & MI & 50 & 75 & 90 \\
\hline 12 & SI & 45 & 55 & 70 \\
\hline 13 & AN & 75 & 80 & 85 \\
\hline 14 & DK & 65 & 75 & 85 \\
\hline 15 & DI & 60 & 75 & 100 \\
\hline 16 & AR & 40 & 65 & 75 \\
\hline 17 & $\overline{P I}$ & 70 & 95 & 95 \\
\hline
\end{tabular}




\begin{tabular}{|c|c|c|c|c|}
\hline 18 & AG & 75 & 90 & 95 \\
\hline 19 & $\mathrm{DA}$ & 65 & 30 & 55 \\
\hline 20 & LA & 75 & 75 & 80 \\
\hline 21 & $\mathrm{DE}$ & 75 & 80 & 80 \\
\hline 22 & MA & 55 & 65 & 75 \\
\hline 23 & DNI & 65 & 55 & 75 \\
\hline 24 & $\mathrm{CA}$ & 70 & 65 & 70 \\
\hline 25 & FI & 55 & 55 & 65 \\
\hline 26 & IM & 65 & 85 & 90 \\
\hline 27 & $\mathrm{RL}$ & 60 & 45 & 75 \\
\hline 28 & DS & 75 & 80 & 80 \\
\hline 29 & ALN & 75 & 80 & 95 \\
\hline 30 & DNA & 75 & 85 & 85 \\
\hline 31 & RR & 65 & 60 & 70 \\
\hline 32 & $\mathrm{MO}$ & 15 & 80 & 90 \\
\hline 33 & PRI & 75 & 65 & 65 \\
\hline 34 & PRA & 75 & 80 & 95 \\
\hline 35 & DWI & 70 & 75 & 100 \\
\hline 36 & ADA & 75 & 65 & 75 \\
\hline 37 & NBA & 65 & 85 & 90 \\
\hline 38 & KTK & 55 & 60 & 75 \\
\hline 39 & MGA & 45 & 40 & 75 \\
\hline 40 & RZK & 40 & 50 & 75 \\
\hline \multicolumn{2}{|c|}{ Number of students } & 40 & 40 & 40 \\
\hline \multicolumn{2}{|c|}{ Total score } & 2450 & 2820 & 3210 \\
\hline \multicolumn{2}{|c|}{ Mean } & 61.3 & 70.5 & 80.3 \\
\hline
\end{tabular}

363 | IJET | Volume. 8, Issue 1. July 2018 
Based on the table above, it was found that the students' speaking skill before the use Ice Breaker strategy was low. It can be seen from the mean of students' score and the percentage of successful students in Pre-Test. There were only 12 out of 40 students whose score reached the minimum category of successful achievement (75), and the mean of students' score in Pre-Test was 61.3. It indicated that students' speaking skill before the use of Ice Breaker strategy was very low. In cycle one, the students' speaking skill after the use of Ice Breaker strategy was still considered somewhat low. It can be seen from the mean of students score and the percentage of successful students in Post-Test I. There were only 21 successful students whose score up to 75, and the mean of students' score in Post Test I was 70.5. It indicated that students' speaking skill after the use of Ice Breaker strategy cycle I had a slight progress.

After making some enhancements in cycle two, the speaking of students significantly increased. It can be seen from the mean of students' score and the percentage of successful students in Post-Test II increased than Post-Test I and Pre-Test. There were 32 successful students whose score up to 75, and the mean of students' score in cycle two was 80.3. It indicated that students' speaking skill in cycle two was considerably high. The enhancement of students' score indicates that the students' speaking skill increased significantly. Therefore, it can be concluded that Ice Breaker strategy can help students in improving speaking skill.

\section{REFERENCES}

Ananda, R., and Syahrum. (2011). Evaluasi Pendidikan. Medan.

Arikunto, S. (2013). Prosedur Penelitian. Jakarta: Rineka Cipta.

Arikunto, S. at all. (2017). Penelitian Tindakan Kelas. Jakarta: Bumi Aksara.

Guntur, T. H. (2008). Berbicara: Sebagai Suatu Keterampilan Berbahasa. Bandung: Angkasa.

Hamzah B. U., \& Mohammad N, (2011). Belajar dengan Pendekatan PAIKEM. Jakarta: PT. Bumi Aksara.

Richards, J. C. (2008). Teaching Listening and Speaking; From Theory to

Practice. New York: Cambridge University Press.

Richards, J. C. (2006). Communicative Language Teaching Today. Cambrigde: Cambridge University Press.

Said, M. (2010). 80 + Ice Breaker Games-Kumpulan Permainan Penggugah Semangat, Yogyakarta: Andi Offset.

Santoso, D. (2017). Keterampilan Berbicara Bahasa Inggris. Medan: Duta Azhar.

Sanjaya, W. (2013). Penelitian Tindak Kelas. Jakarta: Kencana.

Saragih, S.W. (2017). Statistik Pendidikan. Fakultas Tarbiyah UIN Sumatera Utara Medan. Sunarto. (2012). Ice Breaker dalam Pembelajaran Aktif. Surakarta: Yuman Pressindo. 
Ice Breaker

Uzer, U. (2010). Menjadi Guru Profesional. Bandung: Remaja Rosdakarya.

Wijaya, C. \& Syahrum. (2012). Penelitian Tindakan Kelas. Medan: La Tansa Press. 